\title{
INTERNET OF THINGS SYSTEM FOR MONITORING PATIENT'S STATE
}

\author{
Gurko A. G., Al-Dara Ye. N. \\ Kharkiv National Automobile and Highway University
}

\begin{abstract}
Problem. IoT is a technology that is becoming a part of different branches of our life, including healthcare. Currently, some hospitals and other health care facilities in developed countries already use IoT systems for remote monitoring of patients' health. However, most of these systems are expensive, rather complex and are intended for use exclusively by medical staff. All this causes the fact that the mentioned systems remain inaccessible for mass application, and constant control over patients is still carried out by the direct presence of doctors, nurses, etc. At the same time, such continuous observation of the patient also requires quite high financial costs and time. Moreover, some people, e.g. elderly people or people with chronic diseases do not have an opportunity to be constantly under medical care. The purpose of this work is improving the speed and quality of a patient's medical care by monitoring their condition periodically and by rapid remote informing other people about the health state. Method. The IoT-based system to monitor the parameters of a patient's health periodically and send the information to the medical staff or patient's relatives online is offered. The requirements for the system are defined and its architecture is proposed. It consists of an Arduino board, the set of sensors, Internet and GSM modules and the IoT analytics platform. The main health state parameters to be monitored and the corresponding hardware for monitoring the parameters of the patient's state are determined. Results. The prototype of the IoT-based system to monitor a patient's heart rate and send the information through a Cloud IoT platform to the medical staff or the patient's relatives is developed. The results of the experiment on measuring the pulse of 12 people and sending the data to the Cloud showed the efficiency of the system. Conclusions. The developed system can be used either in hospitals or at home. The main advantages of the system are low price, usability, compactness and flexibility in measuring a patient's state parameters. The prospects for further research are connected with equipping the system with a GSM module to send the SMS when any of the parameters have abnormal values and to respond the users' requests about the patient state.
\end{abstract}

Key words: IoT, health state monitoring, heart rate measurement, Arduino.

\section{Introduction}

The rapid development of information and telecommunication technologies have led to the $4^{\text {th }}$ Industrial Revolution (Industry 4.0) the key point of which is integration of Internet of Things (IoT) into all spheres of production and daily life [1]. IoT is a network of physical objects "that have the capacity to auto-organize, share information, data and resources, reacting and acting in face of situations and changes in the environment" [2]. Thus, IoT extends the capabilities of connected devices with new features.

One of the important applications of IoT is healthcare, where it promises technological, economic, and social prospects. Even special terms such as 'e-health' and Internet of Medical Things (IoMT) have been recently introduced [3].

The term 'e-health' is rather fuzzy and is used to refer to everything that is related to computers, Internet and medicine. It also refers to an attitude and commitment to improve healthcare facilities worldwide [4]. One of the most notable trends of e-health is teleconsulting, which helps to deliver the information instantly during medical consultations and discussions of clinical cases [5]. The interval of time during telemedicine consultation between the moment of consultation request and its results is significantly reduced and almost does not differ from that during face-to-face consultations. This allows speeding up the consultation process by reducing the time required to obtain the necessary information about the state of the patient. Moreover, it expands the range of consultants through remote involvement of specialists from other institutions regardless of their locations.

However, there is another way in which the current state of information and telecommunication technologies can help patients. It is remote monitoring of their health state by small wearable devices or implantable sensors [3]. This is the domain of IoMT.

It is well known that there are a very large number of patients and elderly people who are not placed in hospital for some reasons. Those people stay at home under provision of their relatives. In most cases relatives are not able to 
stay constantly near the patient and to monitor his or her health state. In this case, an inexpensive system that can periodically measure the main health parameters of the patient and warn the relatives or/and medical staff in case of any abnormal values can play an important role. After receiving the warning signals from the system, necessary actions can be taken immediately to improve the state of the patient or even to save his or her life. Present work is dedicated to the development of such a system.

\section{Review of the literature}

IoMT plays a vital role in healthcare system nowadays. IoMT devices with modern sensors give the opportunity to monitor health parameters of patients in hospitals or at home automatically and wirelessly. Although IoMT is still in its preliminary stages of development, it has already contributed significantly to the today's growing market of healthcare industry and tomorrow's IoT-based health monitoring solutions. It promises a patient's well-being and safety by coordinating critical patient information and synchronizing related resources instantly through interconnected devices and sensors. [6]. However, there are still many features and directions for the further development of IoMT. Therefore, a large number of studies have been done in the field of IoMT systems.

Many investigations, for instance [7-13], were designated to the development of the structure and capabilities of such systems. For example, in [8] an architecture of a system, based on IoT Ambient Assisted Living System, that helps elderly and disabled people to live independently in a decent way in their own houses and in medical environments, was proposed. The architecture involves providing the following services: home automation, security, ambient intelligence and telemedicine. In [9] an architecture of a system that monitors the health state by an application for smartphones and gives recommendations for patients to improve their eating habits and workout routines, was offered.

In paper [10] an architecture of a cyberphysical system for monitoring the state of cardiological patients taking into account the dynamics of the patients, was described. On the basis of the reference model of the system that monitors the condition of cardiology patients a distributed computing system was developed.

Many studies, for instance Valera et al in [8], reviewed the security issues of confidential data transmission in IoMT.

The architecture an Android Application which provides the end user with visualization of their Electro Cardiogram waves is proposed in [11].

However, most of the previous research do not consider a complete system for monitoring all changes in health parameters of the patient and transmission of the obtained data to the user. One of the examples of a completed system is a system, proposed in [12]. It aims at averting the spread of cancer via early detection, evaluation of disease symptoms, analysing health data and can help healthcare professionals to make evidence-based healthcare decisions to enhance cancer treatment.

Nevertheless, the majority of such systems are expensive (their price can be reach thousands USD) [11] and they are unaffordable for common people due to the high costs. Moreover, most of the smart health monitoring systems available on the market are designed for experts and require special trainings to be done by staff in order to learn how to use these systems. Thus, a low-cost and user-friendly alternative system for monitoring health parameters is vital. Such a system is offered in this work.

One of the ways to reduce the cost and simplify the system is Arduino microcontroller platform, which is widely used for IoT projects due to its low cost and provides rather easy programming and communication with peripherals. That is why Arduino is a perfect base for developing low cost and easy-to-use IoMT systems. A good example of using Arduino for healthcare application is presented in [13], where an anaesthesia control system using Arduino was proposed. It includes a heartbeat sensor and a temperature sensor, which are connected to Arduino Uno to control the dose of anaesthesia administered to the patient. However, the system is not connected to the Internet, so there is not a real IoMT system as far as the data cannot be accessed remotely.

This paper proposes an Arduino-based IoMT system to monitor patient's main health parameters and to send the data to the cloud service so that medical personnel and/or people who look after the patient at home can get access to them whenever they wish.

\section{Purpose and Problem Description}

The object of the research is monitoring physiological state of a patient by processing their health parameters.

The subject of the research is a system for remote monitoring of a patient's state. 
The purpose of the paper is improving the speed and quality of a patient medical care by monitoring their condition periodically and by rapid remote informing other people about the health state.

To achieve this purpose, it is necessary to solve a number of particular tasks:

- analysing the existing solutions for monitoring a patient's condition;

- developing the architecture of the system for monitoring a patient's state;

- selecting the technical means for developing the system;

- developing a prototype of the system.

\section{Architecture of the system}

Based on the above analysis of existing systems, the following architecture for monitoring health parameters of a patient is proposed (Fig. 1). It consists of an Arduino board, which receives output data from the set of sensors connected to it and an Internet module. In the present work, an Ethernet shield is used as the Internet module though other equipment such as ESP8266 module or Wemos D1 can be used as well. Other sensors can also be connected with the Arduino, in the same way, to measure all the necessary parameters depending on the disease. Moreover, a GSM shield can be added to the system in order to provide sending data via the GSM network.

The Arduino processes the received data and sends it through Ethernet shield to a cloud IoT analytics platform where the data is displayed in a created channel in a convenient form (e.g. graphical). In this work the ThingSpeak ${ }^{\mathrm{TM}}$ platform is chosen, that allows a user to aggregate, visualize, and analyse live data streams in the cloud and is free of charge.

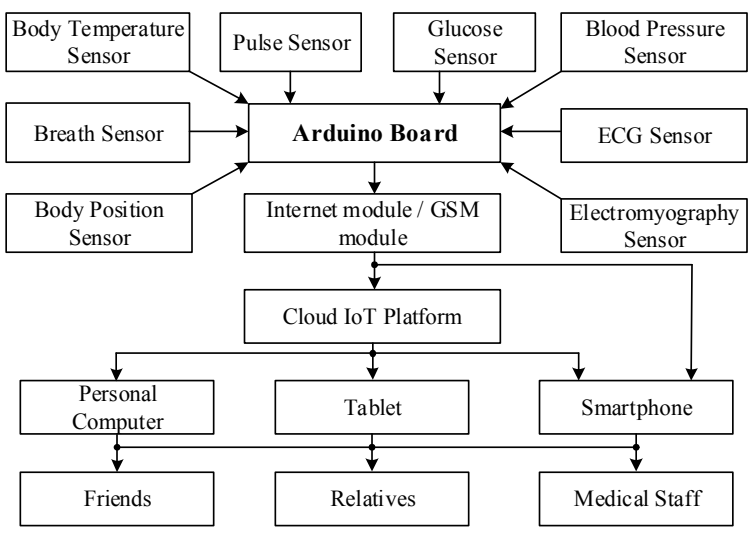

Fig. 1. Architecture of Patient's State Monitoring System
The channel can be accessed by medical staff, friends or relatives using a PC, a smartphone or a tablet. The data in the channel updates automatically. As a result, it will be possible to continuously obtain data for each of the patient's health state parameters.

As shown in Fig. 1 the operation of the system requires the availability of appropriate technical means for measuring health parameters of a patient. Currently, there are many standard and specialized sensors that can be used for these purposes. Some of them are presented in Figs. 2, 3.

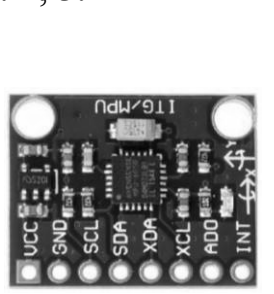

a

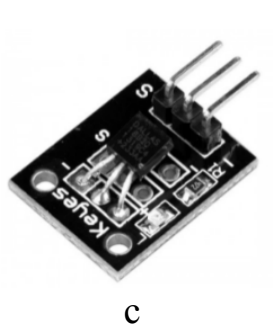

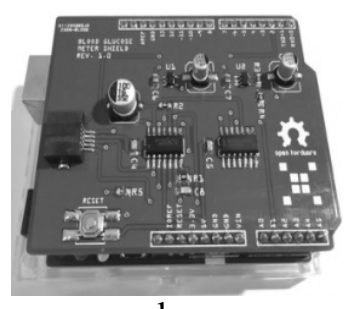

b

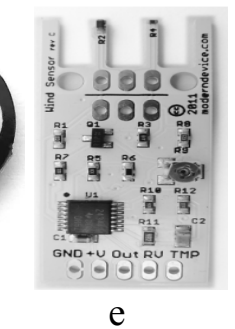

Fig. 2. Standard sensors for Arduino: a - MPU6050 module; $\mathrm{b}$ - glucose meter shield; $\mathrm{c}-$ DS18B20 module; $d$ - pulse sensor; e - air flow sensor MD0550

In particular, we propose to use an MPU6050 accelerometer and gyroscope sensor module to control the position of the patient (Fig. 2,a). To control the concentration of glucose in patient's blood, a glucose meter shield module (Fig. 2,b) is used. The patient's body temperature is measured using the temperature sensors based on the DS18B20 module (Fig. 2, c). The patient's heart rate is measured using a pulse sensor (Fig. 2, d). The air flow sensor MD0550 (Fig. 2, e) allows controlling the patient's breathing (air flow velocity).

If the patient has any diseases that require monitoring additional parameters, additional sensors may be included in the system. With the help of special sensors, some of these additional parameters can be measured. Sphygmomanometers allow measuring patient's arterial pressure (Fig. 3, a) [14].

Electrocardiographs based on the AD8232 ECG module (Fig. 3,b) allow the measurement of electrical and muscular heart function. Elec- 
tromyographs based on the MyoWare ${ }^{\mathrm{TM}}$ (AT-04-001) sensor (Fig. 3,c) allow measuring the electrical activity of muscles [15].

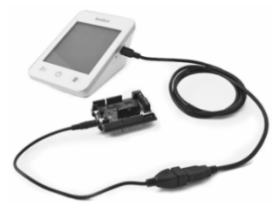

a

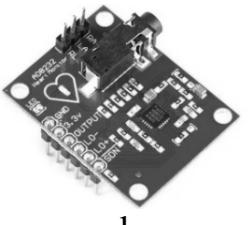

b

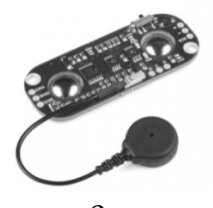

c
Fig. 3. Special sensors for Arduino: a - sphygmomanometer; b - AD8232 ECG module; c- MyoWare ${ }^{\mathrm{TM}}$ (AT-04-001) sensor

\section{Experiments}

In the previous section the architecture of the patient's health state monitoring system was described and patient's health parameters that should be monitored were selected. To test the performance of the system, its first prototype was developed (Fig. 4). As an example, heart beat is considered one of the main parameters of a patient's health state. However, other sensors such as temperature sensor, glucose sensor etc. (Fig. 1) will be added to the system as well.

The prototype of the system consists of (Fig. 4):

- pulse sensor 1 , which is designed to give a digital output of heartbeat when a finger is placed on it. The pulse sensor consists of super bright green LED and a photodetector. In fact, the sensor is a photoplethysmograph: when the heart pumps a pulse of blood through the blood vessels, the finger becomes slightly more opaque and so less light reached the photodetector. With each heart pulse, the detector signal varies. This variation is converted into an electrical signal, which is given to a microcontroller like Arduino. The output signal is also indicated by a LED which blinks at each heartbeat [16];

- Arduino Uno board 2 is based on an ATmega328 which contains everything needed to support the microcontroller and it is connected to a computer with a USB cable. It receives the data from the pulse sensor and processes it;

- Ethernet shield 3. The Arduino Ethernet shield connects the Arduino board to the Internet via an RJ45 cable.

Using the prototype of the system developed and described in the previous section, experiments were conducted in which resting pulses of 12 people of different age categories were measured every $15 \mathrm{~s}$. Resting pulse is the pulse measured when a person is calmly sitting or lying [17].

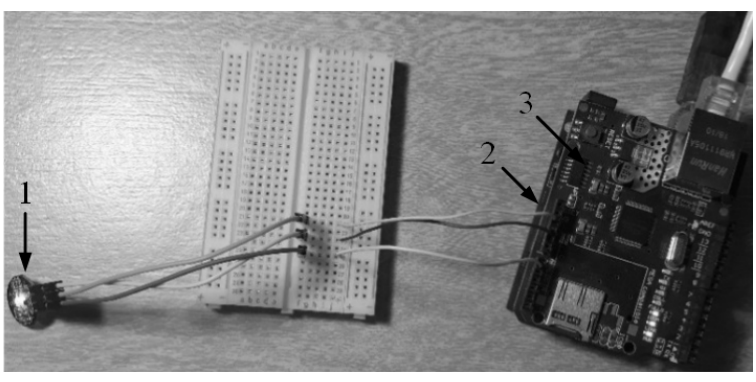

Fig. 4. Hardware of the system: 1 - pulse sensor; 2 - Arduino Uno; 3 - Ethernet shield

The data was processed and sent to the ThingSpeak $^{\mathrm{TM}}$ analytics platform. Any parties concerned who have access can view this data and observe the current value of the pulse, as well as its history in the form of graphs. The experiments conducted allowed us to verify the possibility and effectiveness of using the developed system for remote monitoring of human health state parameters.

\section{Results}

As noted in the previous section, the pulse of 12 people of various age and both genders was measured. These data were sent to the ThingSpeak $^{\mathrm{TM}}$ platform, where they were presented in the graphical form. Some of the graphs are illustrated in Fig. 5. At pulse measuring, its values varied in certain ranges. These ranges, as well as the arithmetical mean of the pulse of each of the participants in the experiment, are given in Tab. 1.

Table 1 - Pulse values of each of the participants in the experiment

\begin{tabular}{|c|c|c|c|c|}
\hline 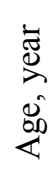 & 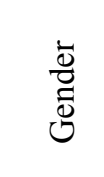 & 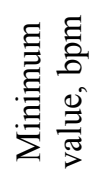 & 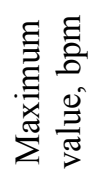 & 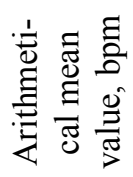 \\
\hline 18 & male & 73 & 77 & 74.3 \\
\hline 22 & female & 67 & 71 & 68.8 \\
\hline 27 & male & 70 & 74 & 71.8 \\
\hline 31 & female & 68 & 73 & 70.4 \\
\hline 40 & female & 72 & 76 & 74.2 \\
\hline 42 & male & 73 & 76 & 74.2 \\
\hline 49 & male & 73 & 76 & 74.6 \\
\hline 53 & female & 73 & 77 & 75.0 \\
\hline 58 & female & 75 & 79 & 76.6 \\
\hline 63 & male & 70 & 75 & 73.0 \\
\hline 71 & female & 73 & 78 & 75.3 \\
\hline 79 & male & 69 & 72 & 70.2 \\
\hline
\end{tabular}



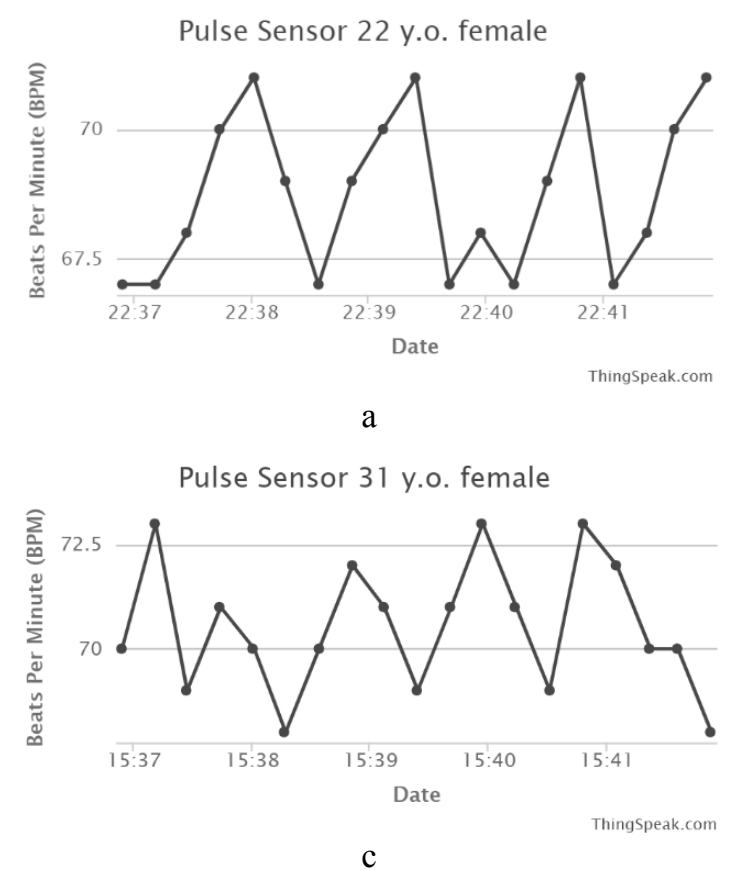

c

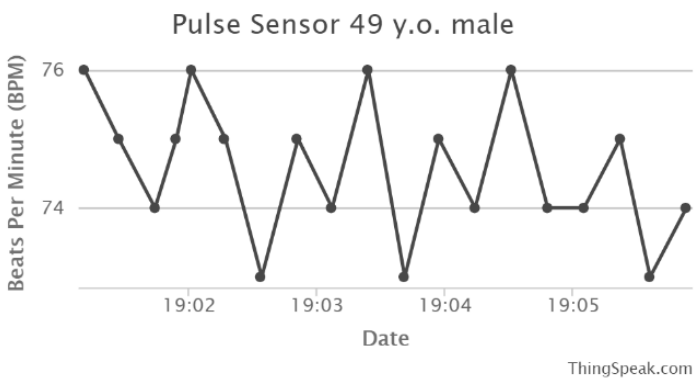

e

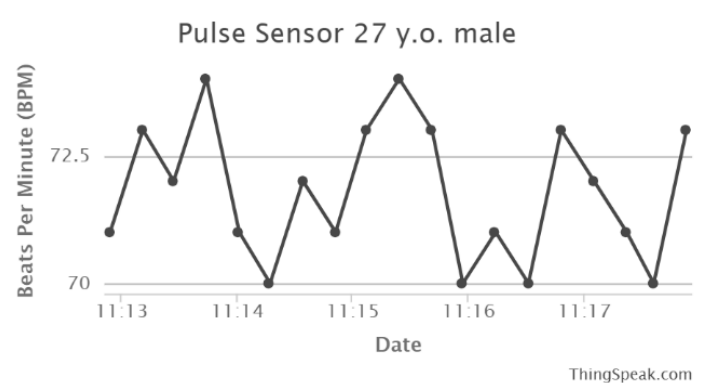

b

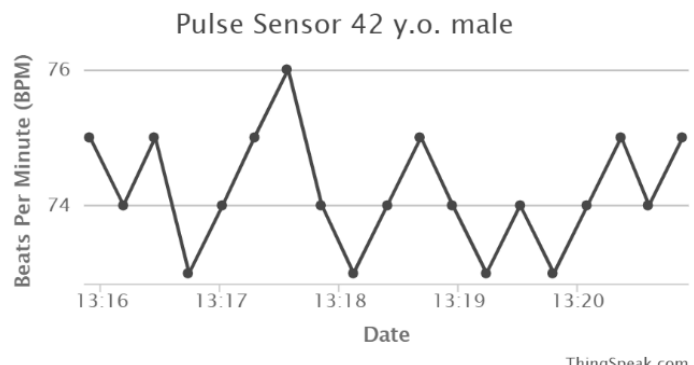

d

Pulse Sensor 79 y.o. male

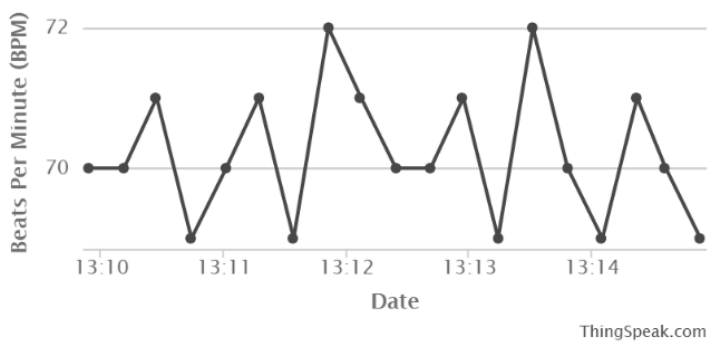

$\mathrm{f}$

Fig. 5. Results of the pulse measurement of various people: $a-22$ years old female; $b-27$ years old male; $c-$

31 years old female; $d-42$ years old male; $e-49$ years old male; $f-79$ years old male

It is known [17, 18], that for adults of 18 or older, a normal resting heart rate is between 60 and 100 beats per minute (bpm) and may vary depending on the age, gender and physical activity. Tab. 2 shows the excellent and average statistical heart rate values of people of different age and gender given in [18].

Table 2 - Pulse of persons of various age and gender in a calm state [18]

\begin{tabular}{|c|c|c|c|c|}
\hline \multirow{2}{*}{$\begin{array}{c}\text { Age, } \\
\text { year }\end{array}$} & \multicolumn{2}{|c|}{$\begin{array}{c}\text { Excellent value, } \\
\text { bpm }\end{array}$} & \multicolumn{2}{c|}{$\begin{array}{c}\text { Average statistical } \\
\text { value, bpm }\end{array}$} \\
\cline { 2 - 5 } & male & female & male & female \\
\hline $18-25$ & $56-61$ & $56-61$ & $70-73$ & $70-73$ \\
\hline $26-35$ & $55-61$ & $60-64$ & $71-74$ & $73-76$ \\
\hline $36-45$ & $57-62$ & $60-64$ & $71-75$ & $74-78$ \\
\hline $46-55$ & $58-63$ & $61-65$ & $72-76$ & $74-77$ \\
\hline $56-65$ & $57-61$ & $60-64$ & $72-75$ & $74-77$ \\
\hline $66+$ & $56-61$ & $60-64$ & $70-73$ & $73-76$ \\
\hline
\end{tabular}

Comparing Tables 1 and 2, we can see that the obtained pulse readings of the participants in the experiment are basically in the range of normal heart rate. This generally confirms the efficiency of the developed system.

At the same time, from Table 1, as well as from Fig. 5 a certain scatter in the pulse readings can be seen, related apparently to the measurement noise. Therefore, to improve the accuracy of measurements, it is advisable to use any of the known filtering methods, for example, moving average method.

\section{Conclusion}

The paper presents the solution of an actual problem of improving the speed and quality of medical care of people with diseases that, for some reasons, are not in the hospital.

The novelty of the paper is in the proposed architecture of the low-cost and easy-to-use IoTbased system for monitoring the patient's state. It consists of Arduino board, the set of sensors, Internet and GSM modules and an IoT analytics platform.

The practical significance of the paper is that the prototype of IoT-based system to moni- 
tor parameters of a patient's health state and send the information to the medical staff or patient's relatives online through a cloud is developed. The system is low-cost and relatively easy in implementation. The results of the experiment, in which the pulse of 12 people was measured and send to the cloud IoT platform, showed the efficiency of the system.

Prospects for further research are connected with:

- adding sensors for measuring other necessary parameters of a patient's health state;

- defining the frequency of these parameters' measurements;

- including a GSM shield to the system to send short messages in case when any of the parameters have abnormal values.

\section{References}

1. Hermann M., Pentek T., Otto B. Design principles for Industrie 4.0 scenarios: a literature review, in Proceedings of the 49th Hawaii international conference on system sciences, 2016, pp. 3928-3937. DOI: 10.1109/HICSS.2016.488

2. Somayya M., Ramaswamy R., Tripathi S. Internet of things (IoT): a literature review. Journal of Computer and Communications, pp. 164-173, 2015. DOI: $10.4236 /$ jcc. 2015.35021

3. Sun W., Cai Z., Li Y. et al. Security and privacy in the medical internet of things: a review, Hindawi: Security and Communication Networks, vol. 2018, Article ID 5978636, p. 9, 2018. DOI: $10.1155 / 2018 / 5978636$

4. Eysenbach G. What is e-health? Journal of Medical Internet Research, vol. 3(2): e20, 2001. DOI:10.2196/jmir.3.2.e20

5. Vladzimirskiy A. V. Telemeditsina [Telemedicine]. Donetsk: Noulidzh, 2011, 436 p. (in Russian)

6. Dharani J., Divya C., Fareen R. F. F. et al. IoT Based Advanced Universal Patient Health (UPH) Observation System Using Raspberry Pi 3B," International Journal of Engineering and Technical Research, vol. 8, N 4, pp. 5-10, 2018.

7. Dimitrov D. V. "Medical internet of things and big data in healthcare, Healthcare Informatics Research, vol. 22, N 3, pp. 156-163, 2016. DOI: 10.4258/hir.2016.22.3.156

8. Valera A. J. J., Zamora M. A., Skarmeta A. F. G. An architecture based on Internet of Things to support mobility and security in medical environments, in Proceedings of the 7th International conference IEEE Consumer communications and networking conference, pp. 1-5, 2010. DOI: 10.1109/ccnc.2010.5421661.

9. Gomez J., Oviedob B., Zhuma E. Patient monitoring system based on Internet of Things, Procedia Computer Science, vol. 83, pp. 90-97, 2016. DOI: $10.1016 / j$.procs.2016.04.103

10. Strihalyuk B. M., Kolodiy R. S., Sekela M. V.
Kiberfizychni tekhnologii monitoryngu stanu kardiolohichnykh patsientiv $\mathrm{v}$ systemi telemedytsyny [Cyberphysical technologies of monitoring the status of cardiac patients in the telemedicine system]. Shtuchnyi Intelekt - Artificial Intelligence, vol. 3, pp. 144-150, 2016 (in Ukrainian).

11. Mohammed J., Lung C.-H., Ocneanu A. et al. Internet of Things: remote patient monitoring using Web services and cloud computing, in Proceedings of IEEE International Conference on Internet of Things, and IEEE Green Computing and Communications and IEEE Cyber, Physical and Social Computing, pp. 256-263, 2014. DOI: 10.1109/ithings.2014.45.

12. Abdel-Basset M., Mohamed M. A novel and powerful framework based on neutrosophic sets to aid patients with cancer, Future Generation Computer Systems, vol. 98, pp. 144-153, 2019. DOI: 10.1016/j.future.2018.12.019

13. Gokilavani R., Gokulapriya M., Jasmine Christy A. R. et al. Anesthesia control system with multi sensor using Arduino, International Journal of Innovative Research in Advanced Engineering, vol. 6, N 3, pp. 86-90, 2019.

14. Blood Pressure Sensor (Sphygmomanometer) v2.0 for e-Health Platform [Biometric / Medical Applications]. Internet: https://www.cookinghacks.com/shop/sensors/e-health/blood-pressuresensor-sphygmomanometer-v2-0 [Jun.18, 2019].

15. MyoWare Muscle Sensor Kit. Available at: https://www.sparkfun.com/products/14409 [Jun.18, 2019].

16. Pulse Sensor Pin and Working Details. Internet: https://www.androiderode.com/pulse-sensor-pinand-working-details/ [Jun.18, 2019].

17. What is a normal heart rate? Available at: https://www.livescience.com/42081-normalheart-rate.html/ [Jun.18, 2019].

18. Kyjanyca O. Normal'nyj pul's: pokaznyky normy dlja cholovikiv i zhinok [Normal heart rate: normal indexes for men and women]. Arrhythmia.center Journal of Heart Health. Available at: https://arrhythmia.center/ua/ normalnyiy-puls-pokazateli-normyi-dlyamuzhchin-i-zhenshhin/ (in Ukrainian) [Jun.18, 2019].

\section{Література}

1. Hermann M. Design principles for Industrie 4.0 scenarios: a literature review / M. Hermann, T. Pentek, B. Otto // 49th Hawaii international conference on system sciences, Koloa, 5-8 January 2016: proceedings. - IEEE, 2016. - P. 39283937. DOI: $10.1109 /$ HICSS.2016.488

2. Somayya M. Internet of things (IoT): a literature review / M. Somayya, R. Ramaswamy, S Tripathi // Journal of Computer and Communications. 2015. - P. 164-173. DOI: $10.4236 / j c c .2015 .35021$

3. Security and privacy in the medical internet of things: a review / [W. Sun, Z. Cai, Y. Li et al.] // 
Hindawi: Security and Communication Networks. - 2018. - Vol. 2018, Article ID 5978636. - 9 p. DOI: $10.1155 / 2018 / 5978636$

4. Eysenbach G. What is e-health? / G. Eysenbach // Journal of Medical Internet Research. - 2001. Vol. 3(2): e20. DOI:10.2196/jmir.3.2.e20

5. Владзимирский А.В. Телемедицина [монография] / А. В. Владзимирский. - Донецк: Изд-во «Ноулидж», 2011. - 436 с.

6. IoT Based Advanced Universal Patient Health (UPH) Observation System Using Raspberry Pi 3B / [J. Dharani, C. Divya, R. F. F. Fareen et al.] // International Journal of Engineering and Technical Research. - 2018. - Vol. 8, N 4. - P. 5-10.

7. Dimitrov D. V. Medical internet of things and big data in healthcare / D. V. Dimitrov // Healthcare Informatics Research. - 2016. - Vol. 22, N 3. - P. 156-163. DOI: 10.4258/hir.2016.22.3.156

8. Valera A. J. J. An architecture based on Internet of Things to support mobility and security in medical environments / A. J. J. Valera, M. A. Zamora, A. F. G. Skarmeta // IEEE Consumer communications and networking conference: 7th international conference, Las Vegas, November 2010: proceedings. - IEEE, 2010. - P. 1-5. DOI: 10.1109/ccnc.2010.5421661.

9. Gomez J. Patient monitoring system based on Internet of Things / J. Gomez, B. Oviedob, E. Zhuma // Procedia Computer Science. - 2016. - N 83. - P. 90-97. DOI: 10.1016/j.procs.2016.04.103

10. Стрихалюк Б. М. Кіберфізичні технології моніторингу стану кардіологічних пацієнтів в системі телемедицини / Б. М. Стрихалюк, Р. С. Колодій, М. В. Секела // Штучний інтелект. 2016. - № 3. - C. 144-150.

11. Internet of Things: remote patient monitoring using Web services and cloud computing / [ J. Mohammed, C.-H. Lung, A. Ocneanu et al.] // IEEE International Conference on Internet of Things, and IEEE Green Computing and Communications and IEEE Cyber, Physical and Social Computing: Taipei, Taiwan, 1-3 September 2014: proceedings. IEEE, 2014. - P. 256-263. DOI:10.1109/ithings.2014.45.

12. Abdel-Basset M. A novel and powerful framework based on neutrosophic sets to aid patients with cancer / M. Abdel-Basset, M. Mohamed // Future Generation Computer Systems. - 2019. Vol. 98. - P. 144-153. DOI: 10.1016/j.future.2018.12.019

13. Anesthesia control system with multi sensor using Arduino / [R. Gokilavani, M. Gokulapriya, A. R. Jasmine Christy et al.] // International Journal of Innovative Research in Advanced Engineering. - 2019. - Vol. 6, N 3. - P. 86-90.

14. Blood Pressure Sensor (Sphygmomanometer) v2.0 for e-Health Platform [Biometric / Medical Applications] [Electronic resource]. - Access mode: https://www.cookinghacks.com/shop/sensors/e-health/blood-pressuresensor-sphygmomanometer-v2-0.
15. MyoWare Muscle Sensor Kit [Electronic resource]. - $\quad$ Access mode: https://www.sparkfun.com/products/14409 (accessed: 18.06.2019.

16. Pulse Sensor Pin and Working Details [Electronic resource]. - $\quad$ Access mode: https://www.androiderode.com/pulse-sensor-pinand-working-details/ (accessed: 18.06.2019.

17. What is a normal heart rate? [Electronic resource]. - $\quad$ Access mode: https://www.livescience.com/42081-normalheart-rate.html/ (accessed: 18.06.2019).

18. Кияница О. Нормальний пульс: показники норми для чоловіків і жінок / О. Кияница // Arrhythmia.center Journal of Heart Health [Електронний ресурс]. - Режим доступу: https://arrhythmia.center/ua/normalnyiy-pulspokazateli-normyi-dlya-muzhchin-i-zhenshhin/ (дата звернення: 18.06.2019).

Gurko A. G., Dr. Sc., professor of automation and computer-integrated technologies department gurko@khadi.kharkov.ua

Al-Dara Ye. N., student, liza.aldara@gmail.com Kharkiv National Automobile and Highway University, 25 Yaroslava Mudroho, Kharkiv, 61002, Ukraine,

\section{Система інтернету речей для моніторингу стану паціснта}

Аннотация. Актуальність. Інтернет речей-иее технологія, яка стає частиною різних галузей нашого життя, включаючи охорону здоров'я. В даний час в розвинених краӥнах деякі лікарні та інші медичні установи вже використовують системи інтернету речей для моніторингу стану здоров'я пацієнтів. Однак більшість з изих систем $\epsilon$ дорогими $і$ досить складними. Крім того, вони призначені для використання виключно медичним персоналом. Все иее призводить до того, щзо зазначені системи залишаються недоступними для масового застосування, а постійне спостереження за пацієнтами як $і$ раніше здійснюється при безпосередній присутності лікарів, медсестер тошчо. У той же час таке постійне спостереження за пацієнтом також вимагає досить високих фінансових витрат та часу. Більи того, деякі люди, наприклад, люди похилого віку або з хронічними захворюваннями не мають можливості постійно перебувати під медичним наглядом. Мета: підвищення швидкості та якості медичної допомоги пацієнтам за рахунок періодичного моніторингу їх стану здоров'я та швидкого дистанційного інформування інших людей про цей стан. Метод. Пропонується система на основі інтернету речей для періодичного моніторингу параметрів стану здоров'я пачіснта та передачі отриманої інформації медичному персоналу або родичам пацієнта в режимі реального часу. Визначено вимоги до системи та запропонована ї архітектура, щуо включає плату Arduіпо, набір датчиків, інтернет і GSM модулі, а також ана- 
літичну платформу для інтернету речей. Визначено основні параметри стану здоров'я пацієнта, щзо необхідно відстежувати, та відповідне обладнання для контролю параметрів стану пацієнта. Результати. Розроблено прототип системи, щзо здійснює моніторинг пульсу пацієнта $i$ відnравку отриманої інформачї через хмарову платформу для інтернету речей медичному персоналу або родичам пацієнта. Результати експерименту по вимірюванню пульсу 12 осіб $і$ відправиі отриманої інформації до хмари показали ефективність роботи системи. Висновки. Розроблена система може використовуватися як в лікарнях, так і вдома. Основною перевагою системи $\epsilon$ низька иіна відносно аналогів, простота у використанні, компактність і гнучкість при вимірюванні різних параметрів стану пацієнта. Подальші дослідження пов'язані 3 оснащенням системи GSM-модулем для відправки SMS в разі, якщио значення будь-якого з параметрів відхиляється від нормального, а також для відповіді на запити користувачів про стан пацієнта.

Ключові слова: інтернет речей, моніторинг стану здоров'я, вимірювання пульсу, Arduino.

Гурко Олександр Геннадійович, д.т.н., проф. каф. автоматизації та комп'ютерно-інтегрованих технологій, gurko@khadi.kharkov.ua

Аль-Дара Єлизавета Намірівна, студентка, liza.aldara@gmail.com,

Харківський національний автомобільнодорожній університет, 61002, Україна, м. Харків, вул. Ярослава Мудрого, 25.

\section{Система интернета вещей для мониторинга} состояния пациента

Аннотация. Актуальность. Некоторые люди, например, пожилье или люди с хроническими заболеваниями не имеют возможности постоянно находиться под медииинским наблюдением.

Целью данной работы является повышение скорости и качества медицинской помощчи паџчентам за счёт периодического мониторинга состояния их здоровья и быстрого дистанционного информирования других людей об этом состоянии. Метод. Предлагается система на основе интернета вещей для периодического мониторинга параметров состояния здоровья пациента и передачи полученной информации медицинскому персоналу или родственникам пачиента в режиме реального времени. Определень требования к системе и предложена ее архитектура, которая включает плату Arduіпо, набор датчиков, интернет и GSM модули, а также аналитическую платформу для интернета вещей. Определены основные параметры состояния здоровья пациента, которые необходимо отслеживать, $u$ соответствующее оборудование для контроля параметров состояния пациента. Результаты. Разработан прототип системы, выполняющий мониторинг пульса пациента и отправку полученной информации через облачную платформу для интернета вещей медицинскому персоналу или родственникам пациента. Результаты эксперимента по измерению пульса 12 человек и отправке полученной информации в облако показали эффективность работы системы. Выводы. Разработанная система может использоваться как в больницах, так и дома. Основным её преимуществом являются низкая ценна, простота в использовании, компактность и гибкость при измерении различных параметров состояния пациента. Дальнейшие исследования связаны с оснащзением системы GSM-модулем для отправки SMS в случае, если значение какого-либо из параметров отклоняется от нормального, а также для ответа на запросы пользователей о состоянии здоровья пациента.

Ключевые слова: интернет вещей, мониторинг состояния здоровья, измерение пульса, Arduino.

Гурко Александр Геннадьевич, д.т.н., проф. каф. Автоматизации и компьютерноинтегрированных технологий, gurko@,khadi.kharkov.ua,

Аль-Дара Елизавета Намировна, студентка, liza.aldara@gmail.com,

Харьковский национальный автомобильнодорожный университет, 61002, Украина, г. Харьков, ул. Ярослава Мудрого, 25. 